\title{
The effects of age, gender and job strain on labour market outflow: an exploratory study
}

Citation for published version (APA):

Diephuis, B. J., Marey, P. S., \& Heijke, J. A. M. (2000). The effects of age, gender and job strain on labour market outflow: an exploratory study. Researchcentrum voor Onderwijs en Arbeidsmarkt, Faculteit der Economische Wetenschappen. ROA Working Papers No. 1E https://doi.org/10.26481/umarow.200001E

Document status and date:

Published: 01/01/2000

DOI:

10.26481/umarow.200001E

Document Version:

Publisher's PDF, also known as Version of record

\section{Please check the document version of this publication:}

- A submitted manuscript is the version of the article upon submission and before peer-review. There can be important differences between the submitted version and the official published version of record.

People interested in the research are advised to contact the author for the final version of the publication, or visit the DOI to the publisher's website.

- The final author version and the galley proof are versions of the publication after peer review.

- The final published version features the final layout of the paper including the volume, issue and page numbers.

Link to publication

\footnotetext{
General rights rights.

- You may freely distribute the URL identifying the publication in the public portal. please follow below link for the End User Agreement:

www.umlib.nl/taverne-license

Take down policy

If you believe that this document breaches copyright please contact us at:

repository@maastrichtuniversity.nl

providing details and we will investigate your claim.
}

Copyright and moral rights for the publications made accessible in the public portal are retained by the authors and/or other copyright owners and it is a condition of accessing publications that users recognise and abide by the legal requirements associated with these

- Users may download and print one copy of any publication from the public portal for the purpose of private study or research.

- You may not further distribute the material or use it for any profit-making activity or commercial gain

If the publication is distributed under the terms of Article $25 \mathrm{fa}$ of the Dutch Copyright Act, indicated by the "Taverne" license above, 


\section{The Effects of Age, Gender and Job Strain on Labour Market Outflow: An Exploratory Study}

ROA-W-2000/1E

Bart J. Diephuis, Hans Heijke and Philip Marey

This study is part of the research program 'Project Education and the Labour Market', subsidised by the Ministry of Education, Culture and Science, the National Centre for Career Issues (LDC), the Ministry of Social Affairs and Employment, the Ministry of Agriculture, Conservation and Fisheries and the Central Employment Board (CBA).

A preliminary version of this paper was presented at the 11th annual EALE-conference in Regensburg, Germany, on September 26th 1999.

\section{Research Centre for Education and the Labour Market}

Faculty of Economics and Business Administration

Maastricht University

Maastricht, March 2000 
ISBN 90-5321-277-9

SEC00.032/HH 


\section{Contents}

Abstract

1 Introduction 1

2 Outflow Determinants Suggested by the Literature 1

3 Data and Methodology 5

4 Stylized Facts 9

5 Outflow Model 12

6 Estimation Results 14

7 Conclusions $\quad 21$

$\begin{array}{ll}\text { References } & 22\end{array}$

$\begin{array}{ll}\text { Appendix } & 25\end{array}$ 



\begin{abstract}
The objective of this study is to improve our understanding of the causes of replacement demand and labour market outflow. A better understanding of the factors that explain why workers flow out is needed for the Netherlands because this country is faced with a particularly high labour market outflow, reflected in a very low participation rate. In our investigation, we focus on different indicators of job strain, as well as variables such as age, gender and job level. We perform both univariate and multivariate regressions to find the effects of these variables on the net flows on the labour market. The regression results reveal that age, gender and (to a lesser extent) job level have the strongest connection with and effect on outflow. The regressions also show that job strain has hardly any noticeable effect on net flow.
\end{abstract}




\section{Introduction}

Between 1997 and 2002, replacement demand is expected to account for almost $65 \%$ of all job openings for school-leavers in the Netherlands (ROA, 1997). Replacement demand occurs because workers retire, become disabled or withdraw (temporarily) from the labour market. Determinants that may play a role, include job strain and institutional factors that affect the participation of workers, such as the participation of women in the labour market in the various stages of their lives (child rearing). The possible connection between job strain and disability outflow is especially relevant for the Netherlands, because the Netherlands show an extremely high disability rate (see De Jong, 1995). This is probably caused mainly by the generous disability insurance system in the Netherlands, rather than a poor overall health of Dutch workers (see Burkhauser et al., 1997).

So, in this paper we try to explore the various influences on labour market outflow. For this purpose we use data on the labour force that indicates the number of workers that leave the working population (by age and gender), and data on the occurrence of job strain. The strong points of the data are that it captures the entire scope of occupations in a typical labour market and that the information stems from individuals. The downside of the data set is that - at least for job strain data - it is static and hence no changes over time can be observed. The opportunity of examining the effects of prolonged exposure to factors that induce job strain is also lost because of this fact.

Section 2 of this paper gives a brief overview of literature concerning job stress and the differences in labour market participation between men and women and the respective age groups. Section 3 describes the data on the labour force and on job strain used in the remainder of the paper. It also gives an outline of the way the labour force data is prepared and adapted for the calculation of the outflow coefficients. Section 4 presents some stylized facts on the distribution of the various job strain indicators over the different occupations and the connection between the occurrence of these indicators and the average outflow. This is followed in section 5 by a description of the outflow model. The main regression results are presented in section 6 . The regressions point again to differences in labour market outflow between men and women and also between different age groups. However, an influence of job strain cannot be demonstrated. The conclusions can be found in section 7 .

\section{Outflow Determinants Suggested by the Literature}

To get an idea of the factors influencing outflow, let us look at one of the 'results' of outflow: participation. Differences in participation rates are obviously closely linked to differences in labour supply and labour market outflow, and it seems prudent to take these findings into account and use them in modelling labour market outflow. High/low outflow numbers are connected to a low/high participation rate. Groups on the labour market that 
exhibit a low participation rate, seem to be characterised by factors that induce either low inflow or high outflow, or both. Let us therefore begin by giving a brief description of the participation rates in the Netherlands and comment on the changes therein. We analysed the Dutch net participation rate of men and women, both separately and together, for the years 1987 to 1997 . Net participation was defined here as the working population (workforce) aged 15 to 64 as a percentage of the total population aged 15 to 64 .

We see a gradual rise in the participation rates over the years. This is especially true for the participation rate of Dutch women. They show a $47 \%$ participation at the end of the period under observation, compared to only $35 \%$ at the beginning in 1987 . This constitutes a dramatic increase of around one third in only ten years. This means that the number of working women between the ages 15 and 64 has risen considerably in the Netherlands. The increased labour market participation for men is less pronounced; rising from $70 \%$ in 1987 to $74 \%$ in 1997. These two increases result in an overall increase in participation in the Netherlands of close to one fifth. Note here that although the participation rate of Dutch women increases significantly when measured in persons, it still falls behind the European average when measured in working hours. This is because over $50 \%$ of working women in the Netherlands work part time and in many cases only work 20 hours a week or less (see Haller et al., 1994; Van Doorne-Huiskes et al., 1995).

Several studies indicate differences in (temporary) outflow between genders, for instance Cuelenaere, Jetten and Van Kooten (1996). In their study of the risks of developing Repetitive Strain Injuries (RSI), Otten, Bongers and Houtman (1998) show that women also run a greater risk of developing RSI than men. But they do not comment on the question whether or not these injuries lead to disability. For other literature, (see Vlasblom 1998 and Vlasblom, De Grip and Van Loo 1998).

Apart from this look at the changes in participation and outflow by gender, we can also investigate Dutch participation rates for the different age groups. We see that the increased overall participation can be attributed mainly to the age groups 25-34, 35-44 and 45-54. Participation of the youngest age category, ages 15-24, remains more or less constant throughout the entire period, while the oldest category shows a minor increase. The observed rise in labour market participation for the three age groups in the middle, is closely linked to the reported increase in participation of women in the Netherlands. A growing number of women in these age groups remain in the labour force or re-enters the labour market after having left it to raise their children. Note that this is only an increase when measured in persons and that the effect is much less pronounced when measured in working hours. With respect to the elderly age group, ages 55-64, note that they can be divided into two separate groups: 55-59 and 60-64. These two groups show some noticeable differences. The former shows a steady increase of participation, from $37 \%$ in 1991 to $42 \%$ in 1997 , whereas the latter shows a constant participation rate of $11 \%$ from 1991 onward. So the workers aged 55 to 59 increase their participation by $5 \%$ points, but those aged 60-64 do not change their rate at all. 
All in all, the data and selected literature demonstrate the differences between men and women and also between the respective age groups when it comes to outflow behaviour and participation on the labour market in the Netherlands.

In recent years, a number of studies also dealt with occupation-specific strain and the effects - either mental or physical - on the worker. Most studies seem to focus more on the psychological effects than the physical effects. If stress becomes too great and people can no longer function properly, they leave the working population and have to rely on social security or disability insurance. In the Netherlands, this is a relatively large group. Statistics Netherlands (CBS) reports that on average around 615,000 persons per year receive this kind of social security. This number has remained more or less constant in recent years and represents a sizeable portion of the entire Dutch labour force. For example, for 1990 CBS gives 621,000 persons on disability insurance and a labour force of $6,063,000$. This constitutes a disability percentage of little over $10 \%$. The benefits paid to this group fluctuate around 13,000 million guilders per year. The Netherlands show some differences when it comes to disability compared to other countries. De Jong (1995) reports that the Netherlands are confronted with disability at least twice as much, and for those under the age of 60 disability prevalence rates are more than triple those in Germany, Sweden and the U.S. And not only is this group comparatively large, but also the average age of Dutch recipients of disability benefits is much lower.

What are the causes of disability and why is it higher in the Netherlands? Gaillard and Kompier (1993), quoting a study by Gründemann et al. (1991), state that in 1990 four out of five disabled workers claimed that work-related mental stress was (partly) to blame for their disablement. Of those who were declared disabled, 35\% was of the opinion that they would not have become disabled if working conditions had been altered or if they had been given different work. Symonds et al. (1995) tested the effects of distributing a psychosocial pamphlet, designed to reduce avoidance behaviour, and showed that this successfully reduced extended absence from low back trouble. Note that there are other possible causes of disability. Non-occupation-related accidents, such as sports injuries or traffic accidents, can also lead to temporary or permanent disability. However, these considerations cannot explain the extremely low Dutch participation rates. Two possible explanations for this are put forward here. First of all, Kerkhofs et al. (1998) state that disability insurance schemes have in the past been used as an exit route for elderly workers (both healthy and unhealthy). This does not, however, explain the low participation rates of young women in the Netherlands. The second reason for the extremely low Dutch participation rates is given by Burkhauser et al. (1997). In his view, the low labour market participation is mainly caused by institutional factors, or more specifically, the generous disability insurance system used in the Netherlands compared to most other countries.

What connection is there between job circumstances and stress or even disability outflow? Kompier (1993) presents a table that shows the main causes of job-related stress. This table is given in a condensed form below. 
Table 2.1

Main causes of job-related stress

Work content

Working conditions

Work regulations

Work relations too much work, too high a pace, too difficult, too easy, too monotonous, too much responsibility, too dangerous

harmful chemicals, noise, vibrating tools or equipment, insufficient lighting, radiation, temperature, draft, humidity, ventilation, bad posture, lack of aids or personal protection

working in shifts, low pay, lack of career opportunities, job security

bad leadership, discrimination, sexual harassment, social isolation at work

Source: adapted from Kompier (1993)

Kompier also refers to Karasek and Theorell (1990), who define two job features which result in the occurrence of stress:

1. The demands of the job;

2. The number of regulatory options or 'controls'.

The first feature - the demands of the job - is the result of the occurrence of the causes mentioned under 'work content' in table 2.1. A job that includes more causes of job-related stress, is termed 'more demanding'. The second feature - controls - has to do with the worker's ability to regulate and control his or her work situation: adjust your pace, taking a break, change your working environment, et cetera. Coping with problems is made easier if one can influence one's work situation. Jobs with fewer possibilities to regulate or control are more demanding because this affects the worker's ability to cope with the causes of stress. Stress as a result of a lack of control options is present mainly in low-level jobs. These jobs are characterised by an imposed structure and pace, for instance working at a conveyor belt.

Houtman, Smulders and Bloemhoff (1993) also mention Karasek's 'job demands-control' model and identify a third stress risk dimension: the social interactions or relationships in the workplace. Having conflicts with colleagues is a significant contributor to work stress, while having social support from your fellow workers provides an important buffer against stress. Using the results of a survey done by Statistics Netherlands (CBS), Houtman, Smulders and Bloemhoff show three factors that are main contributors to work stress:

1. Work pace;

2. Uninteresting work (monotonous, few career opportunities, bad match between job and education);

3. Physical factors (hard work, dangerous work, noise).

Another unlikely indicator is suggested by Zijlstra, Schalk and Roe (1996), who note differences in job stress between so-called 'mental information workers' (i.e. workers that make greater use of new information technology, such as PCs, fax and e-mail) and non- 
mental information workers. They state: 'Information technology leads to an increased independence of workers. That is to say that the individual worker is less bound by regulated working hours or a specific workplace, because of the freedom to work anywhere as a result of working with computers etc.' Their results, however, point to an increase of job pressure and also a diminishing of social contacts at the workplace. They therefore conclude: 'These factors point to a higher stress risk for mental information workers'. This measure of 'information technology' would therefore seem to be another means of clustering occupational classes with the same working conditions.

The participation data as well as the literature therefore point to four elements conducive to outflow: work conditions, the level of the job and the age and the gender of the worker.

\section{Data and Methodology}

In this section, we will present an overview of the data both on the size and composition of the labour force and on job strain. We will also describe the random coefficient model used to model the replacement demand or outflow.

Provided by the Dutch Labour Force Survey (EBB) of Statistics Netherlands (CBS) we have data concerning the number of people working, by occupational class. We distinguish 127 occupational classes for which the time series ranges from 1987 to 1995 . This stock data is available for women and men separately, and is divided into 11 age cohorts, the first 10 of which each spans five years. The first age cohort ranges from age 15 to age 19, and the last one incorporates ages higher than or equal to $65 .^{1}$

Using the aggregated stock data from the Dutch Labour Force Survey (EBB) of Statistics Netherlands (CBS), we can now group the data so that most of the mobility flows can be observed. The data is divided according to age and sex. This is expected to be sufficient to detect most of the mobility processes. After all, the flow into a certain occupational group consists mostly of young people, while the flow out consists mostly of older employees. By making a distinction according to sex, the exit and re-entrance (temporary or not) of women is also captured to a significant extent. (For more information, see Willems and De Grip, 1993.)

Adding the distinction 'age' breaks the stock data up into smaller parts; age cohorts giving rise to a cohort components method (see Shryock and Siegel, 1980), in which the cohortchange rates have to be derived. These rates refer to the number of workers of a certain age in a certain job at two specific points in time.

1. For the first 3 age cohorts, it is assumed that there is no outflow. So the first 3 cohorts remain empty for all years of the data set. 
The cohort-change rates can be written in symbols as:

$$
\ddot{A}_{a, j}^{t 6 t+1}=\frac{L_{a+1, j}^{t+1}}{L_{a, j}^{t}}
$$

where

$$
\begin{aligned}
\ddot{A}_{a, j}^{t 6 t+1}= & \begin{array}{l}
\text { cohort-change rate o f workers with job } \mathrm{j} \text { of cohort } \mathrm{a} \text { at time } \mathrm{t} \\
\text { during period }(\mathrm{t}, \mathrm{t}+1) ;
\end{array} \\
L_{a, j}^{t} \quad= & \text { number of workers with job j of cohort a at time } \mathrm{t} .
\end{aligned}
$$

In economic literature, it is common practice to speak of annual growth (inflow or outflow) rates instead of cohort-change rates:

$$
f_{a, j}^{t 6 t+1}=\frac{L_{a+1, j}^{t+1}}{L_{a, j}^{t}}-1
$$

The previous expression gives the average annual net inflow or outflow rate of the workers in cohort a with occupation $\mathrm{j}$ at time $t$ during period $(t, t+1)$. If the value is less than zero, it refers to a net outflow and if the value is greater than zero, it refers to a net inflow.

For each job and cohort we can derive such a cohort-change rate, or similarly the net inflow or outflow:

$$
F_{a, j}^{t 6 t+1}=L_{a+1, j}^{t+1}-L_{a, j}^{t}=L_{a, j}^{t}\left(1+f_{a, j}^{t 6 t+1}\right)-L_{a, j}^{t}
$$

which is the net inflow or outflow of workers with job $j$ of cohort a at time t during period $(\mathrm{t}, \mathrm{t}+1)$.

Let us describe the statistical outflow model, that is to say, show how the data on the labour force is adapted. The preparation of the data by means of the statistical outflow model is based on the statistical outflow coefficients, which are cohort-specific and genderspecific. The net flow in age cohort a of occupation $j$ between times $t$ and $t+1$ is modelled as: 


$$
f_{a, j}^{t 6 t+1}=f_{a}^{t 6 t+1}+\dot{a}_{a, j}+a_{a, j}^{t 6 t+1}
$$

where

$$
f_{a}^{t 6 t+1}=\text { average net flow in age cohort a between period } \mathrm{t} \text { and } \mathrm{t}+1 \text { over all }
$$

occupations;

$a_{a, j} \quad=$ coefficient to be estimated;

$\mathrm{a}_{a, j}^{t 6 t+1}=$ error term.

This model can be estimated in the following form (move the average net flow to the lefthand side):

$$
f_{a, j}^{t 6 t+1}-f_{a}^{t 6 t+1}=\dot{a}_{a, j}+\stackrel{a}{a, j}_{a, j}^{\dagger t+1}
$$

The equations for the different age cohorts a can then be estimated simultaneously with the use of cohort dummies.

This model uses a very low aggregation level. There are two main objections to this approach. Firstly, there is the possibility of correlation between inflow and outflow rates for different cohorts within an occupation. This can be solved by specifying the model at the level of the job and then control for the cohort effect. The second objection is that a large number of occupations and cohorts leads to few observations for each cohort, which takes away from the explanatory power of the model. This second objection can be overcome in the following way.

Although we have different observations for each job, the sex-age pattern of the net flow coefficients would be similar for the various jobs. We will see this also in Section 4. For almost every occupation, there is outflow from the oldest cohorts and net inflow for the younger age groups. For women, we additionally see an outflow linked to the birth and fostering of children. These similar flow patterns can be incorporated into the model. One way to do this is by pooling the data over the occupations. This multiplies the number of observations for each cohort distinguished. It filters out the effect of 'outliers', but this pooling method has one important disadvantage, in that each occupation will have the same (average) flow coefficients. The variation between the various jobs is completely lost.

This problem can be overcome by specifying a so-called random coefficient model, popularized by Swamy (1970), which implies a systematic way of pooling the data. Such a 
model can be characterized by a position in between the pooling method and the detailed job-by-job model specification. In the random coefficient model, the parameters are the weighted average of the single job-by-job least squares estimation and the average pooled estimation. If the specific estimation is less reliable, more weight will be attributed to the average estimation, and if the specific estimation is very 'sure', the parameters will tend more towards these single estimates.

In order to improve the statistical reliability of the estimated coefficients at this low level of aggregation, we use the random coefficient method. In particular, it is assumed that the coefficients $a_{a, j}$ are drawn from a normal distribution around zero. ${ }^{2}$ After the estimation procedure, the statistical outflow coefficient for age cohort a of occupation $j$ can be estimated as

$$
\tilde{\mathrm{a}}_{a, j}^{t 6 t+1}=\hat{\mathrm{a}}_{a, j}+f_{a}^{t 6 t+1}
$$

The model can be estimated separately for men and women in order to obtain genderspecific statistical outflow coefficients. For an econometric description of random coefficient models, see Judge et al. (1982).

Apart from the net flow data, we also need information on job strain. Each year, CBS takes a sample of the Dutch working population, again for the Dutch Labour Force Survey (EBB), and asks whether or not they encounter one or more indicators of job strain during their work. There are 6 indicators available: noise, vibrating tools or equipment, the use of force, working in shifts, working under pressure of a deadline, and working with information technology (computers). In the survey, there are 4 possible answers: yes (often), yes (sometimes), no and sysmis (or: no answer given). ${ }^{3}$ The results of the individual surveys are then aggregated by occupation, age cohort and gender, and average percentages for each answer are calculated. We focus on the results of the survey done in 1996. These are available by the same 127 occupational classes as were used for the net flow data. In this survey, no distinction is made between men and women. Another negative aspect is that the age classes used in this job strain part of the survey are not the same as the ones found in the replacement outflow data. Here we have 5 age classes, while in the outflow data we had 11 smaller cohorts. The job strain results are not only given by the 5 age classes separately but also for all 5 classes together.

Table A1 in the Appendix gives the percentage of workers that encountered the job strain indicator (i.e. replied 'yes' in the survey). This is done for all 6 indicators and based on the 5

2. In fact, this is a restricted version of the random coefficient model: we set the common mean á equal to zero. This follows from the fact that the equations are estimated in deviations from the average net flow.

3. Answers 'yes (often)' and 'yes (sometimes)' are taken as one in the remainder of this paper. 
age classes together. Looking at the percentages in table $\mathrm{A} 1$, there seems to be an apparent difference between, on the one hand, indicators 1 through 4, and indicators 5 and 6 on the other. For many occupations, high percentages for 'deadline' and 'information technology' coincide with low percentages for the four other indicators. Indicators 5 and 6 are related to inherently different occupations. Taking the average over the occupational classes leads to the percentages in table 3.1.

Table 3.1

Average percentages of workers (men and women) with job strain, by job strain indicator, 1996

Job strain indicator $\quad \%$

Noise

Vibrations

Use of force

Source: CBS/ROA

\section{Stylized Facts}

Using the data on job strain, we divide the 127 occupations into 3 main groups, in order to get an idea of the effects of occupation-specific job strain on net flow. One group of 42 with supposed high job strain, a second group of 43 with average/medium job strain, and a third group of 42 with low job strain. This is done for each of the job strain indicators and for each of the age classes (incl. the total). 'High job strain' is in this case defined as those 42 occupations with the highest percentage of workers that answered 'yes' when asked if they experienced that specific job strain indicator. High level job strain in this report therefore refers to incidence rather than severity of job strain. This distinction is particularly important if the job outflow were only to take place above a certain threshold level of severity of job strain. Another aspect not accounted for in this study is the duration of job strain. The EBB does not provide data on the duration of certain circumstances in the workplace.

Because for all age classes the same occupations are defined as a high, medium or low job strain occupations, we conclude that it is not necessary to make a classification for each age class separately. We base our occupational classification by level of job strain therefore on the data for the total (all age classes aggregated). The results for the 3 job strain levels are shown in table A2 in the appendix.

One thing that is clearly visible in table $A 2$, is the fact that the different indicators do not lead to the same occupational classification. The first 4 indicators (noise, vibrations, force, and working in shifts) clearly form one group, while indicators 5 and 6 (pressure of a 
deadline and working with information technology) form the other. This division more or less follows the traditionally observed blue-collar/white-collar distinction.

We now apply the estimation part of the statistical outflow model for the 'high' and 'low' groups of occupations, based on the classifications in table A2. This is done for all job strain indicators. The average or 'medium' group of occupations is left out, and treated more or less as a buffer between the groups 'high' and 'low'. Think of this buffer as a reference group with a high probability on indifferent results. The model gives as a result the 1016 outflow coefficients, for each occupational class and age cohort. These are then summed over the 'high strain' and 'low strain' groups of occupations. That is to say, they are summed over the 42 occupations within each of the two occupational groups and within each age cohort. For both occupational groups (high and low) a mean coefficient is then calculated. This is done for men and women separately. The resulting average net flow coefficients by age cohort and job strain indicator per occupational group are given in tables $4.1 \mathrm{a}$ and $4.1 \mathrm{~b}$. A negative value denotes net outflow.

Table $4.1 \mathrm{a}$

Average net flow coefficients for occupational classes (men) by job strain level

Men Age cohort

\begin{tabular}{llllllllll}
$\begin{array}{l}\text { Job strain } \\
\text { indicator }\end{array}$ & level & $25-29$ & $30-34$ & $35-39$ & $40-44$ & $45-49$ & $50-54$ & $55-59$ & $60-64$ \\
& & & & & & & & & \\
Noise & high & 0.028 & 0.006 & -0.007 & -0.019 & -0.015 & -0.054 & -0.285 & -0.416 \\
& low & 0.082 & 0.036 & -0.008 & 0.007 & 0.004 & -0.017 & -0.282 & -0.364 \\
Vibrations & high & 0.026 & 0.006 & -0.012 & -0.014 & -0.019 & -0.048 & -0.277 & -0.394 \\
& low & 0.091 & 0.026 & 0.001 & 0.004 & 0.013 & -0.031 & -0.287 & -0.353 \\
& & & & & & & & & \\
Use of force & high & 0.017 & 0.005 & -0.010 & -0.016 & -0.024 & -0.040 & -0.268 & -0.412 \\
& low & 0.110 & 0.036 & 0.004 & 0.010 & 0.019 & -0.034 & -0.287 & -0.384 \\
Working in shifts & high & 0.024 & 0.005 & -0.020 & -0.007 & -0.016 & -0.032 & -0.294 & -0.370 \\
& low & 0.098 & 0.025 & 0.005 & -0.002 & 0.011 & -0.033 & -0.289 & -0.364 \\
\multirow{2}{*}{$\begin{array}{l}\text { Pressure of } \\
\text { deadline }\end{array}$} & high & 0.128 & 0.055 & 0.000 & 0.010 & 0.018 & -0.029 & -0.270 & -0.376 \\
\multirow{2}{*}{$\begin{array}{l}\text { Information } \\
\text { technology }\end{array}$} & low & 0.019 & 0.009 & -0.017 & -0.007 & -0.027 & -0.039 & -0.316 & -0.418 \\
& high & 0.079 & 0.027 & -0.006 & 0.000 & 0.004 & -0.013 & -0.301 & -0.367 \\
\hline
\end{tabular}

Source: ROA

The tables also show the schism between blue-collar and white-collar occupations. For the blue-collar occupations (level 'high' for indicators 1 through 4), the tables show that workers leave the work force sooner. This means that for indicators 1 through 4 , a higher level of job strain leads to net outflow in a younger age cohort than a lower level of job strain would. 
Oddly, the opposite is true for the white-collar occupations. Indicators 5 and 6 with a high level of job strain seem to have lower or later outflow. People who work with computers or work under pressure of a deadline do not leave the workforce as early or in such great numbers as do those who do not work with computers or under pressure of a deadline. This unintuitive result may be explained by taking job level into account because people in high level jobs are assumed to have more regulatory options or controls.

Another observation is that outflow grows with time (age), i.e. more outflow in the later age cohorts. There is one exception: the first age cohort for women. This outflow is more or less what we would expect if we consider that women usually leave the workforce temporarily for child rearing purposes.

Table $4.1 b$

Average net flow coefficients for occupational classes (women) by job strain level

\begin{tabular}{|c|c|c|c|c|c|c|c|c|c|}
\hline \multirow{2}{*}{$\begin{array}{l}\text { Women } \\
\text { Job strain } \\
\text { indicator }\end{array}$} & \multicolumn{9}{|c|}{ Age cohort } \\
\hline & level & $25-29$ & $30-34$ & $35-39$ & $40-44$ & $45-49$ & $50-54$ & $55-59$ & $60-64$ \\
\hline Noise & $\begin{array}{l}\text { high } \\
\text { low }\end{array}$ & $\begin{array}{r}-0.004 \\
0.052\end{array}$ & $\begin{array}{l}0.026 \\
0.037\end{array}$ & $\begin{array}{l}0.026 \\
0.038\end{array}$ & $\begin{array}{l}0.032 \\
0.037\end{array}$ & $\begin{array}{r}-0.011 \\
0.013\end{array}$ & $\begin{array}{r}0.011 \\
-0.012\end{array}$ & $\begin{array}{l}-0.241 \\
-0.244\end{array}$ & $\begin{array}{l}-0.315 \\
-0.362\end{array}$ \\
\hline Vibrations & $\begin{array}{l}\text { high } \\
\text { low }\end{array}$ & $\begin{array}{r}-0.016 \\
0.034\end{array}$ & $\begin{array}{l}0.032 \\
0.035\end{array}$ & $\begin{array}{l}0.025 \\
0.035\end{array}$ & $\begin{array}{l}0.029 \\
0.038\end{array}$ & $\begin{array}{r}-0.020 \\
0.012\end{array}$ & $\begin{array}{l}-0.013 \\
-0.026\end{array}$ & $\begin{array}{l}-0.245 \\
-0.241\end{array}$ & $\begin{array}{l}-0.320 \\
-0.358\end{array}$ \\
\hline Use of force & $\begin{array}{l}\text { high } \\
\text { low }\end{array}$ & $\begin{array}{r}-0.014 \\
0.083\end{array}$ & $\begin{array}{l}0.029 \\
0.043\end{array}$ & $\begin{array}{l}0.023 \\
0.040\end{array}$ & $\begin{array}{l}0.034 \\
0.037\end{array}$ & $\begin{array}{r}-0.001 \\
0.022\end{array}$ & $\begin{array}{r}-0.037 \\
0.000\end{array}$ & $\begin{array}{l}-0.236 \\
-0.251\end{array}$ & $\begin{array}{l}-0.376 \\
-0.338\end{array}$ \\
\hline Working in shifts & $\begin{array}{l}\text { high } \\
\text { low }\end{array}$ & $\begin{array}{r}-0.013 \\
0.038\end{array}$ & $\begin{array}{l}0.027 \\
0.030\end{array}$ & $\begin{array}{l}0.021 \\
0.034\end{array}$ & $\begin{array}{l}0.041 \\
0.038\end{array}$ & $\begin{array}{l}0.002 \\
0.012\end{array}$ & $\begin{array}{l}-0.022 \\
-0.015\end{array}$ & $\begin{array}{l}-0.247 \\
-0.233\end{array}$ & $\begin{array}{l}-0.357 \\
-0.334\end{array}$ \\
\hline $\begin{array}{l}\text { Pressure of } \\
\text { deadline }\end{array}$ & $\begin{array}{l}\text { high } \\
\text { low }\end{array}$ & $\begin{array}{r}0.113 \\
-0.023\end{array}$ & $\begin{array}{l}0.048 \\
0.022\end{array}$ & $\begin{array}{l}0.035 \\
0.021\end{array}$ & $\begin{array}{l}0.039 \\
0.035\end{array}$ & $\begin{array}{r}0.015 \\
-0.008\end{array}$ & $\begin{array}{l}-0.022 \\
-0.029\end{array}$ & $\begin{array}{l}-0.268 \\
-0.240\end{array}$ & $\begin{array}{l}-0.329 \\
-0.374\end{array}$ \\
\hline $\begin{array}{l}\text { Information } \\
\text { technology }\end{array}$ & $\begin{array}{l}\text { high } \\
\text { low }\end{array}$ & $\begin{array}{r}0.021 \\
-0.009\end{array}$ & $\begin{array}{l}0.036 \\
0.029\end{array}$ & $\begin{array}{l}0.026 \\
0.024\end{array}$ & $\begin{array}{l}0.039 \\
0.038\end{array}$ & $\begin{array}{l}0.014 \\
0.000\end{array}$ & $\begin{array}{l}-0.014 \\
-0.040\end{array}$ & $\begin{array}{l}-0.197 \\
-0.233\end{array}$ & $\begin{array}{l}-0.335 \\
-0.377\end{array}$ \\
\hline
\end{tabular}

Source: ROA

The results presented in tables $4.1 \mathrm{a}$ and $4.1 \mathrm{~b}$ can also be shown in a graphical form. For example, figure 4.1 gives the graph for women and for the indicator 'working in shifts'. In this example one can observe more clearly the pattern of higher outflow for the elderly, with exception of the first age class. Note also the fact that the line for those experiencing the job strain indicator is below the other line, indicating more outflow. This feature is also present for indicators 1 through 3. For indicators 5 and 6 , the relative position of the two lines will typically be the other way around. The graphs for men will be comparable, apart from the outflow in the first age cohort. 
Figure 4.1

Net flow by 'working in shifts' for women

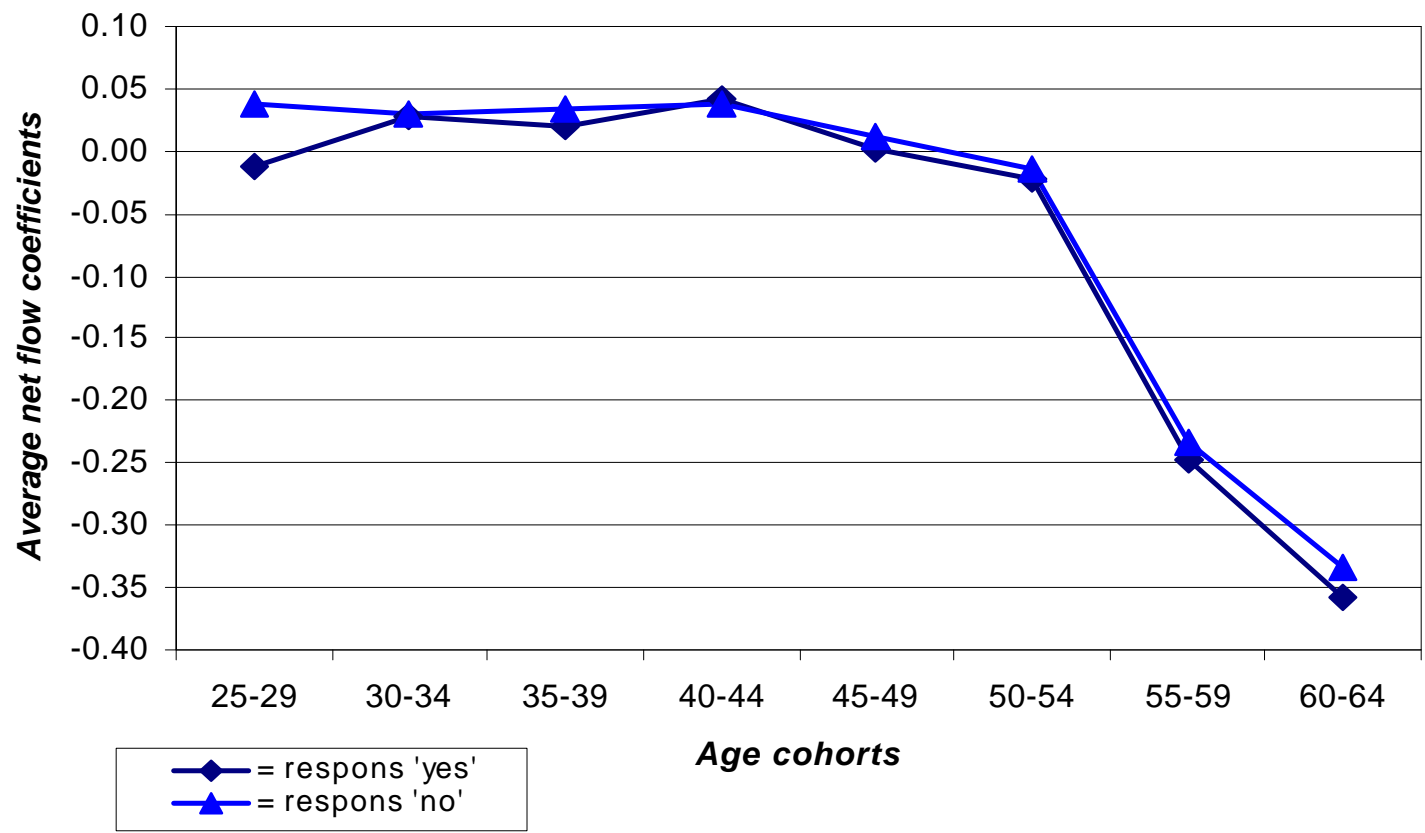

\section{Outflow Model}

Previous results suggest that different indicators of job strain do affect the outflow coefficients. There also is a systematic distribution of outflow coefficients over the different age cohorts and the resulting outflow pattern differs by gender. In this section, we therefore propose an outflow model which explains outflow coefficients from the different aspects of job strain, allowing for different effects by gender and by age cohort.

Recall:

$$
f_{a, j}^{t 6 t+1}=f_{a}^{t 6 t+1}+\dot{a}_{a, j}+\stackrel{a}{a, j}_{a t+1}
$$

with statistical outflow coefficient

$$
\tilde{a}_{a, j}^{t 6 t+1}=a_{a, j}+f_{a}^{t 6 t+1}
$$

In our outflow model, we now try to explain the outflow coefficient for age cohort a of occupation $\mathrm{j}$ in period $\mathrm{t}$ from outflow-determinants, as follows:

$$
\tilde{\mathrm{a}}_{a, j}^{t 6 t+1}=x_{a, j}^{t 6 t+1} \hat{\mathrm{a}}_{a, j}
$$


where

$$
\begin{aligned}
& x_{a, j}^{t 6 t+1}=\text { row vector of outflow determinants } \\
& \hat{\mathrm{a}}_{a, j}=\text { column vector of coefficients }
\end{aligned}
$$

The outflow determinants that we will focus on, are several aspects of job strain, job level, gender and age (cohort).

The outflow model can therefore be written as

$$
f_{a, j}^{t 6 t+1}=x_{a, j}^{t} \hat{a}_{a, j}+\stackrel{a}{a}_{a, j}^{t 6 t+1}
$$

Currently, there is no time series available for the six job strain variables. The outflow model will therefore have to be estimated by a two-step procedure. The first step is to estimate the outflow coefficients according to the random coefficient method of the statistical outflow model (see also the following subsection). The second step is to perform an OLS regression of the estimated statistical outflow coefficients on the cross-section observations for the determinants.

The first step of the two-step procedure is to estimate the net flow coefficients according to the random coefficient model of the statistical outflow model. This gives us the endogenous variable needed in our OLS regression: the net flow coefficients. We now assume these coefficients to be affected by several variables: gender, age, the level of the job, and job strain indicators. We introduce:

$$
\begin{array}{ll}
1 \text { gender dummy } & : \text { male }=1 \text {, female }=0 \\
8 \text { age cohort dummies } & : \text { cohort }=1 \text {, not }=0 \\
1 \text { job level dummy } & : \text { high level }=1 \text {, low level }=0 .
\end{array}
$$

An F-test rejects the hypothesis that the determinants/variables are not gender-specific and we will therefore only perform the regressions separately for men and women, i.e. we discard the gender dummy. ${ }^{4}$

4. We compare two models. The first is a model using all variables (cohorts, job strain indicators, job level) and a gender dummy. The second (restricted) model does not use a gender dummy, but takes all other variables to be gender-specific, i.e. doubles each variable into a male or female equivalent. The F-test then tests the hypothesis, whether or not you should use genderspecific variables.

F-test: $\ddot{e}_{1}=($ restricted RSS - unrestricted RSS $) /\left(\mathrm{J}^{*} \mathrm{o}^{2}\right)=1.901$. Here $\ddot{e}_{1}$ follows a F-distribution with $\mathrm{J}(=15)$ and T-K $(=2032-30=2002)$ degrees of freedom. A $\ddot{e}_{1}$ of 1.9 rejects the nullhypothesis $\left(\mathrm{H}_{0}=\right.$ variables are not gender-specific) at a 5\%-level. So, we should use different models per gender and we do so in the remainder of this paper. 
The fourth suggested determinant of net flow is job strain. The data (percentages) on job strain is not gender-specific, that is to say it is assumed that men and women experience the same job strain when performing the same tasks. A drawback of the data on job strain is that it is given for 5 age classes instead of the 8 age cohorts used by the statistical model. There is also an age class 6 , which simply is the total of all 5 classes. Job strain data in class 6 therefore pertains to all ages ranging from 15 to 64 . As before, we will use the data as given by age class 6 .

The job strain indicators can be modelled as percentages or as dummies, which group together the occupations with similar (high/low) job strain occurrences. The two dummies are not each other's complements, because of the buffer group separating them. We will choose using the following dummies (based on the percentages of class 6):

$$
\begin{array}{lll}
6 \text { low job strain dummies } & : & \text { low strain }=1 \text {, not }=0 \\
6 \text { high job strain dummies } & : & \text { high strain }=1, \text { not }=0,
\end{array}
$$

because the loss of information has no effect on the results.

\section{Estimation Results}

\section{Univariate results using dummies based on non-differentiated job strain data}

First, we present the results of univariate regressions for the different job strain indicators and job level excluded as an explanatory variable. We will only present the results for one job strain indicator here as an example. The results for 'pressure of deadline' are given in the following table. This table also shows the results of the regression with job level as an explanatory variable.

We see that fewer occurrences of job strain (level=low) have a negative sign for men as well as women. This negative sign means that encountering less job strain due to working with the pressures of a deadline coincides with negative net flow, i.e. outflow larger than inflow. More job strain (level=high) has a positive sign, denoting the fact that a high level of job strain coincides with positive net flow or inflow greater than outflow. This is similar to the results in tables $4.1 \mathrm{a}$ and $4.1 \mathrm{~b}$.

Table 6.2 on the next page gives the univariate regression results (in sign and significance) for all 6 job strain indicators. The estimates of the cohort dummies are left out for reasons of clarity. What can we conclude on the basis of the results shown in table 6.2? Let us begin by looking at the results of the regressions for men. The regression without job level as an explanatory variable shows again the difference between the first four job strain indicators and the last two. A high level of noise, vibrating tools, the use of force, or working in shifts coincides with negative net flow, i.e. outflow greater than inflow. The opposite 
holds for high levels of time pressure and working with information technology. As before, we attribute this result to the level of the job. We assume that most of the people who said that they worked with deadlines or computers were also the ones having a high level job. Jobs at a higher level provide more regulatory options ('controls') and therefore the means of dealing with job stress due to, for instance, working with deadlines. If this is in fact the case, then the introduction of a job level variable should reverse the signs of job strain indicators 5 (and 6). The job level variable is a dummy, with $1=$ high level and $0=$ low level. We expect job level to have a positive sign, meaning that having a high level job is linked to inflow greater than outflow. No change in sign of job strain indicators 5 and 6 is observed when the regression is performed with job level as an extra explanatory variable. Job level is not even significantly different from 0 for 'pressure of a deadline'. The only signs that change are those of high levels in the use of force and working in shifts, but not significantly. Despite the lack of impact of job level, we should note that this variable is nevertheless significant in four out of six regressions.

Table 6.1

OLS regression results for indicator 5 (pressure of deadline), with and without job level ${ }^{1}$

\begin{tabular}{|c|c|c|c|c|c|}
\hline \multicolumn{2}{|l|}{ Model } & \multicolumn{2}{|c|}{ without job level } & \multicolumn{2}{|c|}{ with job level } \\
\hline Variable & denoting/level & men & women & men & women \\
\hline Cohort 1 & $25-29$ & $0.083648 *$ & $0.028584^{*}$ & $0.082478^{*}$ & $0.025607^{*}$ \\
\hline Cohort 2 & $30-34$ & $0.026330^{*}$ & $0.028892^{*}$ & $0.025160^{\star}$ & $0.025915^{\star}$ \\
\hline Cohort 3 & $35-39$ & $-0.023228^{*}$ & $0.019657^{*}$ & $-0.024398^{\star}$ & 0.016680 \\
\hline Cohort 4 & $40-44$ & 0.009649 & $0.017911^{*}$ & 0.008479 & 0.014934 \\
\hline Cohort 5 & $45-49$ & $-0.033346^{\star}$ & $-0.022198^{\star}$ & $-0.034516^{\star}$ & $-0.025175^{\star}$ \\
\hline Cohort 6 & $50-54$ & $-0.017843^{\star}$ & $-0.033339^{\star}$ & $-0.019013^{\star}$ & $-0.036316^{*}$ \\
\hline Cohort 7 & $55-59$ & $-0.294346^{\star}$ & $-0.135315^{\star}$ & $-0.295516^{\star}$ & $-0.138292^{*}$ \\
\hline Cohort 8 & $60-64$ & $-0.324531^{*}$ & $-0.269648^{*}$ & $-0.325701^{*}$ & $-0.272625^{\star}$ \\
\hline Pressure of deadline & low & $-0.011124^{*}$ & $-0.023392^{*}$ & $-0.010588^{\star}$ & $-0.022028^{*}$ \\
\hline Pressure of deadline & high & $0.017171^{*}$ & 0.009986 & $0.015804^{\star}$ & 0.006508 \\
\hline Job level & high & - & - & 0.002960 & 0.007530 \\
\hline
\end{tabular}

1) ${ }^{*}=$ statistically significant at $5 \%$ significance level

The separate regressions for women give different results. They have a less favourable 'goodness of fit' than the separate regressions for men and some of the resulting signs are not what we would expect intuitively. This occurs three times: for a high level of noise and for both high and low levels of the indicator 'vibrating tools'. For noise, the estimate is even significantly different from zero. It is not clear what causes these results or how they should be interpreted. Adding the job level variable does not change the sign of any job strain indicator at either level. For women, job level is significantly different from zero (with the expected sign) for three out of six regressions. 
Table 6.2

Effects of an increase in job strain on the net flow, results of univariate regressions for all job strain indicators, using dummies based on non-differentiated job strain data , with and without job level ${ }^{1}$

\begin{tabular}{|c|c|c|c|c|c|}
\hline \multicolumn{2}{|l|}{ Model } & \multicolumn{2}{|c|}{ without job level } & \multicolumn{2}{|c|}{ with job level } \\
\hline Variable & level & men & women & men & women \\
\hline Noise & low & positive & positive & positive & positive \\
\hline Noise & high & negative & positive* & negative & positive* \\
\hline Job level & high & - & - & positive* & positive* \\
\hline Vibrating tools & low & positive & negative & positive & negative \\
\hline Vibrating tools & high & negative* & positive & negative & positive* \\
\hline Job level & high & - & - & positive* & positive* \\
\hline Use of force & low & positive* & positive & positive* & positive \\
\hline Use of force & high & negative & negative* & positive & negative \\
\hline Job level & high & - & - & positive & positive \\
\hline Working in shifts & low & positive* & positive & positive* & positive \\
\hline Working in shifts & high & negative & negative & positive & negative \\
\hline Job level & high & - & - & positive* & positive* \\
\hline Pressure of deadline & low & negative* & negative* & negative* & negative* \\
\hline Pressure of deadline & high & positive* & positive & positive* & positive \\
\hline Job level & high & - & - & positive & positive \\
\hline Inform. technology & low & negative* & negative* & negative & negative \\
\hline Inform. technology & high & positive & positive & positive & positive \\
\hline Job level & high & - & - & positive* & positive \\
\hline
\end{tabular}

$1)^{*}=$ statistically significant at $5 \%$ significance level

The univariate regressions of this subsection have also been performed using dummies based on the differentiated data. That is to say, use different data - and therefore different dummies - per age class. The use of non-differentiated data instead of differentiated data results in only very few and very minor changes in sign and significance. The same goes for the use of the original percentages (either differentiated or not) instead of dummies. In each instance, the division between the first 4 indicators and the last 2 , is observed and the addition of job level as a variable shows again a positive sign and significance in most cases. $^{5}$

5. For more detailed information on these regressions and their outcomes, as well as regression results that are left out in the remainder of this paper, the reader is referred to the authors. 
So far, we performed the regressions separately for all job strain indicators. Now we will model all job strain indicators simultaneously. The job strain dummies are again constructed on the basis of data from class 6 (non-differentiated). Tables 6.3 and 6.4 again show the results for men and women separately, with and without job level as an explanatory variable.

Table 6.3

OLS regression results multivariately for all job strain indicators, using dummies based on class 6 data, without job level ${ }^{1}$

\begin{tabular}{|c|c|c|c|}
\hline Variable & denotes/level & men & women \\
\hline Cohort 1 & $25-29$ & $0.077841^{*}$ & 0.017679 \\
\hline Cohort 2 & $30-34$ & $0.020524^{*}$ & 0.017987 \\
\hline Cohort 3 & $35-39$ & $-0.029035^{*}$ & 0.008752 \\
\hline Cohort 4 & $40-44$ & 0.003843 & 0.007006 \\
\hline Cohort 5 & $45-49$ & $-0.039153^{\star}$ & -0.033103 \\
\hline Cohort 6 & $50-54$ & $-0.023650^{\star}$ & $-0.044244^{x}$ \\
\hline Cohort 7 & $55-59$ & $-0.300153^{\star}$ & $-0.146220^{x}$ \\
\hline Cohort 8 & $60-64$ & $-0.330338^{\star}$ & $-0.280553^{*}$ \\
\hline Noise & low & -0.002100 & 0.006630 \\
\hline Noise & high & -0.000515 & $0.022379^{*}$ \\
\hline Vibrating tools & low & 0.000846 & $-0.022121^{x}$ \\
\hline Vibrating tools & high & -0.003572 & 0.015374 \\
\hline Use of force & low & 0.004885 & 0.015217 \\
\hline Use of force & high & 0.003260 & -0.016676 \\
\hline Working in shifts & low & 0.009947 & 0.007532 \\
\hline Working in shifts & high & 0.005519 & -0.002462 \\
\hline Pressure of deadline & low & -0.009376 & $-0.024140^{x}$ \\
\hline Pressure of deadline & high & $0.018450^{\star}$ & 0.007793 \\
\hline Inform. technology & low & -0.000001 & 0.002829 \\
\hline Inform. technology & high & -0.003739 & 0.007214 \\
\hline
\end{tabular}

$1)^{*}=$ statistically significant at $5 \%$ significance level

In what way are the results of the multivariate regression different from the results of the univariate regressions? For men, we see different signs for low level noise and for high level use of force, working in shifts, and information technology. In this multivariate regression, working with computers does lead to net outflow for men (has a negative sign), albeit insignificantly, but low level information technology is also linked to net outflow for men (its sign has not changed). For women, there is only one sign different when compared to the univariate regressions: low level information technology has become 
positive. This result is not very strong either, since high level information technology is also positive and neither is significant. Multivariate regression has fewer statistically significant job strain indicators than the univariate regressions.

Table 6.4

OLS regression results multivariately for all job strain indicators, using dummies based on class 6 data, with job level ${ }^{1}$

\begin{tabular}{llll}
\hline Variable & denotes/level & men & women \\
\hline Gender & male & - & - \\
Cohort 1 & $25-29$ & $0.077148^{*}$ & 0.015009 \\
Cohort 2 & $30-34$ & $0.019830^{*}$ & 0.015317 \\
Cohort 3 & $35-39$ & $-0.029728^{*}$ & 0.006083 \\
Cohort 4 & $40-44$ & 0.003149 & 0.004337 \\
Cohort 5 & $45-49$ & $-0.039846^{*}$ & $-0.035772^{*}$ \\
Cohort 6 & $50-54$ & $-0.024343^{*}$ & $-0.046913^{*}$ \\
Cohort 7 & $55-59$ & $-0.300846^{*}$ & $-0.148890^{*}$ \\
Cohort 8 & $60-64$ & $-0.331031^{*}$ & $-0.283222^{*}$ \\
& & & \\
Job level & high & 0.001168 & 0.004498 \\
Noise & low & -0.002131 & 0.006513 \\
Noise & high & -0.000529 & $0.022324^{*}$ \\
Vibrating tools & low & 0.000849 & $-0.022108^{*}$ \\
Vibrating tools & high & -0.003494 & 0.015672 \\
Use of force & low & 0.004855 & 0.015100 \\
Use of force & high & 0.003553 & -0.015550 \\
Working in shifts & low & 0.009757 & 0.006801 \\
Working in shifts & high & 0.005801 & -0.001377 \\
Pressure of deadline & low & -0.009314 & $-0.023900^{*}$ \\
Pressure of deadline & high & $0.018129^{*}$ & 0.006560 \\
Inform. technology & low & 0.000135 & 0.003353 \\
Inform. technology & high & -0.003636 & 0.007613 \\
\hline
\end{tabular}

$1)^{*}=$ statistically significant at $5 \%$ significance level

This concludes the results of the multivariate regression without job level. In table 6.4, the results are shown of regressions using job level as an additional explanatory variable. Job level has a positive sign when added to the model. Adding job level changes the sign of low level information technology for men from negative to positive, making this more in line with our intuition. For women, there are no signs reversed as a result of to the addition of the job level variable. When we compare the results with those of the univariate regressions when they were performed including job level, we see for men changes for low level noise and information technology and high level information technology and for women for low level information technology. Not all sign changes are changes for the better. Some signs 
change from intuitively correct or expected to unexpected. However none of the changed signs is statistically significant.

Again the multivariate regressions of this subsection have also been performed using dummies based on the differentiated job strain data (differentiated by age cohort). The use of non-differentiated data instead of differentiated data this time results in quite a few but very minor changes in sign. This occurs mostly in the regressions for men. Most of the reversed signs are not statistically significant. The addition of job level as a variable again shows a positive sign. As before in the multivariate regression, however, the estimated coefficient is not significantly different from 0 . The use of the original percentages (either differentiated or not) instead of dummies, again not reported here, also makes very little difference indeed.

\section{Multivariate results using percentages based on differentiated job strain data}

We have so far performed regressions univariately (job strain indicators separately) and multivariately (simultaneously for all job strain indicators). We could also combine some of the job strain indicators and form one or two new job strain indicators. In this subsection, we will test two such combinations. Here we will also depart from our dummy approach and use the original percentages of the Dutch Labour Force Survey (EBB). Furthermore, we will differentiate this data. Instead of using the data of class 6 (the total of all 5 age classes), we will in this subsection use different job strain data per age class.

Because of the differences in size between the age classes of the job strain data and the age cohorts of the model, i.e. age classes spanning either 5 or 10 years, we assign the data of:

$\begin{array}{lll}\text { class } 1 & \text { to } & \text { cohort } 1 \\ \text { class } 2 & \text { to } & \text { cohorts } 2 \text { and } 3 \\ \text { class } 3 & \text { to } & \text { cohorts } 4 \text { and } 5 \\ \text { class } 4 & \text { to } & \text { cohorts } 6 \text { and } 7 \\ \text { class } 5 & \text { to } & \text { cohort } 8 .\end{array}$

As was stated above, we will look at two new job strain indicators by combining several indicators. The new variables are constructed simply by taking the average of the percentages of the indicators which are to be combined.

The first combination that we consider is provided by the suggested blue-collar/white-collar division observed in the graphs: combine indicators 1 through 4 (i.e. noise, vibrating tools, use of force, and working in shifts) and 5 and 6 (i.e. pressure of deadline and information technology) to make two new indicators. The results (with and without job level) are given in table 6.5. 
The estimated model with combined indicators 1-4 and 5-6 fit reasonably well, showing insignificance for cohorts 2 and 4 and for indicators 1-4 (all for the regression for men only). In the regressions without job level as a variable, we see that pressure of deadline combined with working with information technology (indicators 5,6) has a significantly positive sign for both men and women. So, working with a combination of these job strain indicators has a positive effect on net flow, i.e. reduces the outflow compared to the inflow, which was not expected. The results are not so strong for the combined indicator made up of the first 4 job strain indicators. Only for women is it significant. But it has an unexpected positive sign. This result therefore does not show the expected higher outflow due to physically taxing work. For men, the sign is indeed negative, but not significantly so. Adding job level as an explanatory variable has the greatest effect in the regression for women. This effect is however more an effect on the size of the estimated coefficient, than on the signs of coefficients of the job strain indicators. The only two sign changes are not significant.

Table 6.5

Regressions for men and women with job strain indicators 1-4 and 5-6 combined, with and without job level ${ }^{1}$

Without job level with job level

\begin{tabular}{|c|c|c|c|c|c|}
\hline Variable & denotes & men & women & men & women \\
\hline Cohort 1 & $25-29$ & $0.061949^{*}$ & $-0.028979 *$ & $0.059224^{*}$ & $-0.036772^{*}$ \\
\hline Cohort 2 & $30-34$ & 0.002019 & $-0.032894^{*}$ & -0.000277 & $-0.039461^{*}$ \\
\hline Cohort 3 & $35-39$ & $-0.047539^{*}$ & $-0.042129^{*}$ & $-0.049835^{\star}$ & $-0.048696^{*}$ \\
\hline Cohort 4 & $40-44$ & -0.014542 & $-0.043185^{\star}$ & -0.016769 & $-0.049553^{*}$ \\
\hline Cohort 5 & $45-49$ & $-0.057537^{*}$ & $-0.083294^{*}$ & $-0.059764^{*}$ & $-0.089662^{*}$ \\
\hline Cohort 6 & $50-54$ & $-0.039904^{*}$ & $-0.090008^{*}$ & $-0.042303^{*}$ & $-0.096871^{*}$ \\
\hline Cohort 7 & $55-59$ & $-0.316407^{*}$ & $-0.191985^{\star}$ & $-0.318807^{*}$ & $-0.198848^{*}$ \\
\hline Cohort 8 & $60-64$ & $-0.344176^{*}$ & $-0.320798^{*}$ & $-0.346682^{*}$ & $-0.327965^{\star}$ \\
\hline Job level & high & - & - & 0.008095 & $0.023152^{*}$ \\
\hline Indicators 1-4 & blue collar & -0.000106 & $0.062999^{*}$ & 0.011266 & $0.095522^{*}$ \\
\hline Indicators 5,6 & white collar & $0.039235^{\star}$ & $0.068747^{\star}$ & $0.033750^{*}$ & $0.053060^{*}$ \\
\hline
\end{tabular}

$1)^{*}=$ statistically significant at $5 \%$ significance level

A second combination of job strain indicators is 3 and 4 together and 1, 2, 5 and 6 together. For the results of the regressions with this grouping (with and without job level), see table 6.6. Define job strain indicator 3-4 as the new blue-collar work indicator and indicator 1-2-5-6 as the new white-collar work indicator. The new white-collar indicator again has an unexpected positive sign which is significant for all four regressions in table 6.8. Adding job level does not change this sign. This confirms once again the idea that the sign of this indicator is not due to ignoring the level of the job. Job level does not seem to add vital information, since it does not change the signs of the newly constructed job strain 
indicators in the theoretically expected direction and since it is itself not significantly different from zero.

Table 6.6

Regressions for men and women with job strain indicators 3-4 and 1-2-5-6 combined, with and without job level ${ }^{1}$

\begin{tabular}{|c|c|c|c|c|c|}
\hline \multirow[b]{2}{*}{ Variable } & \multirow[b]{2}{*}{ denotes } & \multicolumn{2}{|c|}{ Without job level } & \multicolumn{2}{|c|}{ with job level } \\
\hline & & men & women & men & women \\
\hline Cohort 1 & $25-29$ & $0.069031^{*}$ & $-0.028957^{*}$ & $0.063649^{*}$ & $-0.034910^{*}$ \\
\hline Cohort 2 & $30-34$ & 0.009457 & $-0.033942^{*}$ & 0.004526 & $-0.039397^{*}$ \\
\hline Cohort 3 & $35-39$ & $-0.040101^{*}$ & $-0.043177^{\star}$ & $-0.045032^{*}$ & $-0.048631^{*}$ \\
\hline Cohort 4 & $40-44$ & -0.007335 & $-0.044658^{\star}$ & -0.012096 & $-0.049924^{*}$ \\
\hline Cohort 5 & $45-49$ & $-0.050330^{*}$ & $-0.084767^{\star}$ & $-0.055091^{*}$ & $-0.090033^{*}$ \\
\hline Cohort 6 & $50-54$ & $-0.033486^{*}$ & $-0.091675^{\star}$ & $-0.038209^{*}$ & $-0.096900^{*}$ \\
\hline Cohort 7 & $55-59$ & $-0.309989^{*}$ & $-0.193652^{*}$ & $-0.314712^{*}$ & $-0.198876^{*}$ \\
\hline Cohort 8 & $60-64$ & $-0.339148^{*}$ & $-0.323644^{*}$ & $-0.343532^{*}$ & $-0.328493^{*}$ \\
\hline Job level & high & - & - & 0.009678 & 0.010705 \\
\hline Indicators 3,4 & blue collar & $-0.027755^{\star}$ & -0.023007 & -0.010349 & -0.003753 \\
\hline Indicators $1,2,5,6$ & white collar & $0.057005^{\star}$ & $0.148781^{*}$ & $0.049851^{*}$ & $0.140868^{*}$ \\
\hline
\end{tabular}

$1)^{*}=$ statistically significant at $5 \%$ significance level

\section{Conclusions}

In the next few years, most job openings for school-leavers in the Netherlands are expected to arise from replacement demand as a result of labour market outflow. The need to understand labour market outflow is also especially great because of the very low participation rate. Different indicators of job strain affect the outflow coefficients and there also appears to be a systematic pattern of outflow coefficients with respect to age, gender and job level.

The unavailability of time series data on job strain forced us to use a two-step procedure, while of the three determinants age, gender and job strain, only age and gender turned out to be significant in affecting the net flow coefficients. That is to say, we found that the variables were gender-specific and the cohort variables were significantly different from zero (this holds especially for the later cohorts, i.e. the older workers). These results are consistent with both our intuition and the literature. The job strain indicators were on average not statistically significant, with the exception of indicator 5 , pressure of deadline. The job strain indicators were only significant in univariate regressions, but several times the signs of the job strain indicators were in contradiction with our earlier findings. 
Moreover, the possibility of an omitted variable bias makes these results less reliable. Note that we could have used the 'no' percentages also, making it easier to compare 'dummy results' with 'percentage results'. Using only the 'yes (often)' percentages instead of the sum of the 'yes (often)' and 'yes (sometimes)' percentages, might also be an useful variation, but this last variation leads to similar results (not reported in this paper).

On the basis of these results, we conclude that age and gender are the main determinants of outflow, whereas job strain provides little additional information. This conclusion is valid for all categories: either dummies or percentages, with or without job level as an explanatory variable, and for either level of job strain.

Certain comments should be made with regards to the data. The flow data used in this study is net flow data. It is our assumption that gross flow data, making a clear distinction between inflow and outflow, would correspond better with job strain data. With regard to the job strain data, it should again be noted that it says nothing about the severity of the job strain, but that it is instead only a measure of the incidences/occurrences of job strain. This distinction is particularly important if the job outflow only takes place above a certain threshold level of severity of job strain. Another aspect not accounted for in this study, is the duration of job strain. That is to say, the time an individual worker is subjected to a certain (indicator of) job strain.

A (micro) data set, better suited to the needs of an investigation into the connection between job strain and labour outflow, may very well yield different results.

\section{References}

Bastelaer, A. van, and E. Hoogteijling (1995), Participation and Non-Participation in a European Perspective; in T. Jaspers et al. (eds.) (1995), Working Policies? Facts, Analyses and Policies Concerning Employment and Non-Participation in the Netherlands, Wolters-Noordhoff, Groningen, pp. 1-34.

Bullinga, R. and F. Nijhuis (1990), Ziekteverzuim, Arbeidsongeschiktheid, Herintrede in de Limburgse Industrie, Department of Medical Psychology, Maastricht University, Maastricht.

Burkhauser, R.V., D. Dwyer, M. Lindeboom, J. Theeuwes, and I. Woittiez (1997), Health, Work and Economic Well-Being of Older Workers, Aged 51 to 61: A Cross-National Comparison using the United States HRS and the Netherlands CERRA Data Sets, Aging Studies Program Paper no. 11. Center for Policy Research, Syracuse University.

Cuelenaere, B., B. Jetten, and G. Van Kooten (1996), Verschillen in Ziekteverzuim tussen Mannen en Vrouwen? Verklaringen Onderzocht, Tijdschrift voor Arbeidsvraagstukken, vol. 12, no. 1, pp. 43-55. 
Doorne-Huiskes, A. van and J. Schippers (1995), Women's Low Labour Market Participation in the Netherlands: Cultural Restrictions or Lack of Facillities; in T. Jaspers et al. (eds.), (1995), Working Policies? Facts, Analyses and Policies Concerning Employment and Non-Participation in the . Netherlands, Wolters-Noordhoff, Groningen, pp. 119-146.

Gaillard, A.W.K., and M.A.J. Kompier (1993), Werkstress en Arbeidsongeschiktheid; in A.W.K. Gaillard, A.W.K., and M.A.J. Kompier (1993), Werkstress en Arbeidsongeschiktheid: Preventie en Interventie, Antwerp: MAKLU, pp. 11-23.

Gründemann, R.W.M., I.D. Nijboer and A.J.M. Schellart (1991), Arbeidsgebondenheid van WAOIntrede, Ministry of Social Affairs and Employment, S-127, The Hague.

Haller, M., and F. Hoellinger (1994), Female Employment and the Change of Gender Roles: The Conflictual Relationship Between Participation and Attitudes in International Comparison, International Sociology, vol. 9, no. 1, pp. 87-112.

Houtman, I.L.D., P.G.W. Smulders and A. Bloemhoff (1993), Werkstress Risico's in Bedrijf en Beroep: Ontwikkelingen in de Tijd; in A.W.K. Gaillard and M.A.J. Kompier (eds.) (1993). Werkstress en Arbeidsongeschiktheid: Preventie en Interventie, Antwerp: MAKLU, pp. 25-46.

Jong, Ph. de (1995), Unemployment and Disability; in T. Jaspers, et al. (eds.), Working Policies? Facts, Analyses and Policies Concerning Employment and Non-Participation in the Netherlands, Wolters-Noordhoff, Groningen, pp. 81-104.

Judge, G.G., R.C. Hill, W.E. Griffiths, H. Lütkepohl and T.C. Lee (1982), Introduction to the Theory and Practice of Econometrics, John Wiley \& Sons, Inc, New York.

Karasek, R.A., and T. Theorell (1990), Healthy Work. Stress, Productivity and the Reconstruction of Working Life, Basic Books, New York.

Kerkhofs, M., M. Lindeboom, and J. Theeuwes (1998), Retirement, Financial Incentives and Health. Research Memorandum 1998-42, Applied Labour Economics Research Team (ALERT), Department of Economics, Free University, Amsterdam.

Kompier, M.A.J. (1993), Werkstress en Werkdruk: Van Probleem tot Oplossing; in A.W.K. Gaillard and M.A.J. Kompier (eds.), (1993), Werkstress en Arbeidsongeschiktheid: Preventie en Interventie, Antwerp: MAKLU, pp. 47-65.

Otten, F., P. Bongers, and I. Houtman (1998), De Kans op RSI in Nederland: Gegevens uit het Permanent Onderzoek Leefsituatie 1997, Maandbericht Gezondheidsstatistiek, CBS 98/11, pp. 515.

Researchcentrum voor Onderwijs en Arbeidsmarkt (1997), De Arbeidsmarkt naar Opleiding en Beroep tot 2002, ROA-R-1997/7, Maastricht, Maastricht University.

Shryock, H.S., J.S. Siegel (1980), The Methods and Materials of Democracy, Bureau of the Census, United States.

Swamy, P.A.V.B. (1970), Efficient Inference in a Random Coefficient Regression Model. Econometrica, vol. 38, pp. 311-323. 
Symonds, T.L., A.K. Burton, K.M. Tillotson, and C.J. Main (1995), Absence Resulting from Low Back Trouble Can Be Reduced by Psychosocial Intervention at the Work Place, Spine, vol. 20, no. 24, pp. 2738-2745.

Vlasblom, J.D. (1998), Differences in Labour Supply and Income of Women in the Netherlands and the Federal Republic of Germany, Ph.D. thesis, Utrecht, Utrecht University.

Vlasblom, J.D., A. De Grip, and J. Van Loo (1997), Arbeidsmarktperspectieven voor Meisjes en Allochtonen, ROA-R-1997/9, Maastricht, Maastricht University.

Willems, E., and A. De Grip (1993), Forecasting Replacement Demand by Occupation and Education, International Journal of Forecasting, vol. 9, pp. 173-185.

Zijlstra, F.R.H., M.J.D. Schalk and R.A. Roe (1996), Veranderingen in Arbeid: Consequenties voor Werkenden, Tijdschrift voor Arbeidsvraagstukken, vol. 12, no. 3, pp. 251-263. 


\section{Appendix}

Table A1

Percentage of workers (men and women) with job strain, by occupational class and job strain indicator, 1996

Primary school teachers

Teachers of science, medical, hotel and catering subjects (2nd and 3rd degree)

Teachers of science, medical, hotel and catering subjects (1st degree and UE)

Agricultural and technical teachers (2nd and 3rd degree)

Agricultural and technical teachers (1st degree and UE)

Teachers of economic and administrative subjects (2nd and 3rd degree)

Teachers of economic and administrative subjects (1st degree and UE)

Language and arts teachers

Language teachers (1st degree and UE)

Teachers of social, psychological subjects (2nd and 3rd degree)

Teachers of social subjects (1st degree and UE) 2nd and 3rd degree teachers no specialisation

1 st degree teachers, no specialisation

Pedagogical staff

Educational scientists and pedagogues

Driving instructors

Swimming instructors

Sports instructors

Interpreters, translators and writers

Library assistants

Librarians

Graphic designers

Artists

Pastoral workers

Theologians

Journalists

Linguists

Agricultural auxiliary workers

Agricultural workers

Skilled agricultural workers

Environmental hygienists and agricultural representatives

Agricultural scientists

Agricultural machine drivers and fishermen

Agricultural managers

Production workers

Laboratory assistants

Laboratory workers

Technical analysts

Physicists

$\begin{array}{rrrrrr}- & - & - & - & 65 & 81 \\ - & - & - & - & - & 100 \\ 51 & 58 & 64 & - & 63 & - \\ 31 & 38 & 66 & - & 67 & 40 \\ 52 & 30 & 61 & 21 & 51 & 18 \\ - & - & - & - & - & - \\ - & - & - & - & 56 & 88 \\ - & - & - & - & 54 & 93 \\ - & - & - & - & 70 & 97\end{array}$


Table $A 1$ (continued)

Percentage of workers (men and women) with job strain, by occupational class and job strain indicator, 1996

Caretakers

Heads of technical service departments

Mechanical engineers

Construction workers

Contractors and fitters

Architects and construction project manager

Civil engineers

Civil engineering workers

Skilled civil engineering workers

Civil engineering designers and project leaders

Metalworkers

Welders and bench fitters

Metal-processing managers

Assembly-line workers

Mechanics

Mechanical engineering designers and heads of technical service departments

Electronical engineers

Fitters and electronic product controllers

Electrical engineers

Electrotechnical designers and managers

Electrical engineers

Printing industry production workers

Skilled printing workers

Mechanical operators

Process operators

Process technicians.

Material scientists

Textile workers

Cobblers and tailors

Loaders and unloaders

Drivers

Ship's officers and conductors

Pilots, ship captains and transport directors

Stewards

Nursing aids and student nurses

Nurses and medical assistants

Therapists and nurses

Physicians

Pharmacy assistants medical laboratory staff

Medical analysts

Pharmacists

Department heads in care institutions

Office assistants, packers and door-to-door salesmen

Auxiliary administrative assistants

Managers

Economists

Production planners

$$
\begin{array}{r}
21 \\
- \\
52 \\
46 \\
18 \\
- \\
57 \\
49 \\
- \\
72 \\
64 \\
4 \\
44 \\
60 \\
\\
25 \\
- \\
33 \\
42 \\
- \\
36 \\
48 \\
60 \\
67 \\
- \\
4 \\
46 \\
- \\
30 \\
24 \\
56 \\
35 \\
56 \\
11 \\
9 \\
4 \\
- \\
- \\
- \\
- \\
- \\
- \\
-
\end{array}
$$$$
21
$$

$\begin{array}{rr}- & - \\ - & -\end{array}$

18

57

49

72

$64 \quad 52$

$44 \quad 46$

$60 \quad 53$

10
50

12

$46 \quad 19$

$-\quad 68$

$87 \quad 96$

45

$\begin{array}{lll}- & - & 69\end{array}$

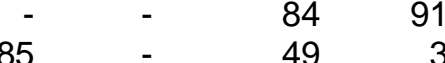

$\begin{array}{llll}67 & - & 60 & 26\end{array}$

$\begin{array}{llll}- & - & 83 & 83\end{array}$

$\begin{array}{lll}- & 87 & 90 \\ - & 44\end{array}$

$\begin{array}{llll}80 & - & 57 & 30\end{array}$

$\begin{array}{llll}- & - & 59 & 82\end{array}$

$\begin{array}{llll}69 & 19 & 52 & 20\end{array}$

$\begin{array}{llll}58 & 17 & 57 & 32\end{array}$

$66 \quad 26$

$\begin{array}{llll}66 & 16 & 60 & 39\end{array}$

$\begin{array}{llll}- & - & 75 & 88\end{array}$

$60 \quad 81$

$54 \quad 41$

$62 \quad 42$

7198

7293

$72 \quad 56$

$68 \quad 48$

$54 \quad 26$

$67 \quad 73$

$61 \quad 85$

$77 \quad 89$

$56 \quad-$

81

$59 \quad 7$

$67 \quad 69$

$77 \quad 86$

91

73

$71 \quad 50$

$\begin{array}{ll}79 & 45 \\ 83 & 69\end{array}$

$59 \quad 76$

$64 \quad 91$

$87 \quad 93$

$66 \quad 71$

$-$

- 10

$13 \quad 10$

$74 \quad 88$ 
Table $A 1$ (continued)

Percentage of workers (men and women) with job strain, by occupational class and job strain indicator, 1996

Organisational consultants

Organisational experts

Receptionists and administrative employees

Accountants and secretaries

Assistant accountants

Accountants

Insurance brokers

Purchasing clerks

Commercial staff

Technical and commercial employees

Technical and administrative staff

Legal and tax office employees

Legal staff and higher civil servants

Lawyers

Administrative transport employees

Managers

Managing directors

Medical secretaries

Programmers

Systems analysts

Information scientists

Technical systems analysts

Activity supervisors and employment intermediaries

Socio-cultural workers

Social counsellors and heads of personnel

Social-science staff

Social researchers

Shelf stockers

Cleaning staff

Sales assistants

Shopkeepers

Auxiliary catering and service workers

Home nursing personnel

Catering personnel

Pub and snackbar owners

Catering managers

Bakers and butchers

Trainee policemen, soldiers and assistant

Policemen, police officers and security employees

Police inspectors and senior officers

Firemen security personnel

a

\begin{tabular}{|c|c|c|c|c|c|}
\hline- & - & - & - & 77 & 94 \\
\hline - & - & - & - & 86 & 95 \\
\hline 10 & - & 11 & 7 & 52 & 87 \\
\hline 7 & - & 6 & - & 61 & 96 \\
\hline 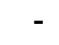 & - & 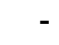 & - & 74 & 97 \\
\hline- & - & - & - & 87 & 98 \\
\hline - & - & - & - & 65 & 88 \\
\hline 7 & - & 9 & 2 & 64 & 86 \\
\hline 6 & - & 5 & - & 77 & 91 \\
\hline- & - & - & - & 62 & 58 \\
\hline- & - & - & - & 75 & 91 \\
\hline- & - & - & - & 64 & 95 \\
\hline- & - & - & - & 85 & 93 \\
\hline- & - & - & - & 81 & 92 \\
\hline- & - & - & - & 77 & 88 \\
\hline 12 & - & 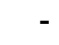 & - & 86 & 82 \\
\hline 6 & - & 6 & - & 85 & 76 \\
\hline- & - & - & - & 60 & 99 \\
\hline- & - & - & - & 67 & 100 \\
\hline- & - & - & - & 82 & 99 \\
\hline- & - & - & - & 78 & 100 \\
\hline - & - & - & - & 85 & 99 \\
\hline 15 & - & 27 & 11 & 48 & 55 \\
\hline 10 & - & 8 & - & 71 & 81 \\
\hline - & - & - & - & 80 & 80 \\
\hline - & - & - & - & 85 & 100 \\
\hline - & - & - & - & 75 & 84 \\
\hline 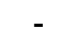 & - & 61 & - & 42 & \\
\hline 17 & 11 & 56 & 8 & 42 & - \\
\hline 10 & 4 & 44 & 4 & 39 & 27 \\
\hline 8 & 5 & 49 & - & 58 & 56 \\
\hline 19 & 5 & 58 & 13 & 54 & 6 \\
\hline 10 & - & 86 & 44 & 75 & 10 \\
\hline 23 & 4 & 61 & 20 & 57 & 14 \\
\hline - & - & 51 & - & 72 & - \\
\hline 23 & - & 39 & 19 & 59 & 42 \\
\hline 38 & - & 80 & - & 73 & - \\
\hline 23 & 13 & 25 & 46 & 43 & 62 \\
\hline 22 & - & 28 & 43 & 69 & 91 \\
\hline - & - & 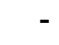 & - & 90 & 92 \\
\hline . & - & - & - & - & \\
\hline
\end{tabular}

Source: CBS/ROA 
Occupational job strain level, by job strain indicator, 1996

noise

vibrations force

shifts

deadline IT

Primary school teachers

Teachers of science, medical, hotel and catering subjects (2nd and 3rd degree)

Teachers of science, medical, hotel and catering subjects (1st degree and UE)

Agricultural and technical teachers (2nd and 3rd degree)

Agricultural and technical teachers (1st degree and UE)

Teachers of economic and administrative subjects (2nd and 3rd degree)

Teachers of economic and administrative subjects (1st degree and UE)

Language and arts teachers

Language teachers (1st degree and UE)

Teachers of social, psychological subjects (2nd and 3rd degree)

Teachers of social subjects (1st degree and UE)

2nd and 3rd degree teachers no specialisation

1st degree teachers, no specialisation

Pedagogical staff

Educational scientists and pedagogues

Driving instructors

Swimming instructors

Sports instructors

Interpreters, translators and writers

Library assistants

Librarians

Graphic designers

Artists

Pastoral workers

Theologians

Journalists

Linguists

Agricultural auxiliary workers

Agricultural workers

Skilled agricultural workers

Environmental hygienists and agricultural representatives

Agricultural scientists

Agricultural machine drivers and fishermen

Agricultural managers

Production workers

Laboratory assistants

Laboratory workers

Technical analysts

Physicists

Caretakers

Heads of technical service departments

Mechanical engineers

Construction workers

\begin{tabular}{|c|c|c|c|c|c|}
\hline high & low & medium & low & low & low \\
\hline high & medium & low & low & low & medium \\
\hline medium & medium & low & low & medium & medium \\
\hline high & high & medium & low & low & medium \\
\hline medium & low & low & low & medium & high \\
\hline medium & low & low & low & medium & medium \\
\hline $\begin{array}{l}\text { low } \\
\text { high } \\
\text { medium }\end{array}$ & $\begin{array}{l}\text { low } \\
\text { medium } \\
\text { low }\end{array}$ & $\begin{array}{l}\text { low } \\
\text { medium } \\
\text { low }\end{array}$ & $\begin{array}{l}\text { low } \\
\text { low } \\
\text { low }\end{array}$ & $\begin{array}{l}\text { medium } \\
\text { low } \\
\text { medium }\end{array}$ & $\begin{array}{l}\text { high } \\
\text { low } \\
\text { medium }\end{array}$ \\
\hline high & low & high & low & low & low \\
\hline medium & low & low & low & medium & medium \\
\hline high & medium & medium & low & low & medium \\
\hline high & high & medium & low & high & medium \\
\hline low & low & low & low & high & medium \\
\hline low & low & low & low & high & medium \\
\hline low & medium & low & medium & low & low \\
\hline high & medium & medium & high & low & low \\
\hline high & medium & high & medium & low & low \\
\hline low & low & low & high & medium & medium \\
\hline low & low & medium & medium & low & high \\
\hline low & low & medium & low & low & high \\
\hline low & low & low & low & high & high \\
\hline medium & medium & medium & medium & high & medium \\
\hline low & low & low & low & high & medium \\
\hline low & low & low & low & medium & medium \\
\hline low & low & low & medium & high & high \\
\hline low & medium & medium & medium & high & high \\
\hline medium & medium & high & low & low & low \\
\hline high & high & high & medium & low & low \\
\hline medium & high & high & medium & low & low \\
\hline low & medium & medium & low & medium & medium \\
\hline medium & medium & medium & low & high & high \\
\hline high & high & high & medium & medium & low \\
\hline high & high & high & low & medium & low \\
\hline high & high & high & high & low & low \\
\hline high & high & high & high & medium & medium \\
\hline medium & high & medium & high & low & high \\
\hline medium & high & medium & medium & low & high \\
\hline low & medium & low & medium & medium & high \\
\hline medium & high & high & high & low & low \\
\hline high & high & medium & low & medium & medium \\
\hline $\begin{array}{l}\text { migh } \\
\text { higm }\end{array}$ & $\begin{array}{l}\text { medigh } \\
\text { high }\end{array}$ & high & medium & $\begin{array}{l}\text { nign } \\
\text { low }\end{array}$ & $\begin{array}{l}\text { nign } \\
\text { low }\end{array}$ \\
\hline
\end{tabular}


Table A2 (continued)

Occupational job strain level, by job strain indicator, 1996

noise

vibrations force

shifts

deadline IT

Architects and construction project manager

Civil engineers

Civil engineering workers

Skilled civil engineering workers

Civil engineering designers and project leaders

Metalworkers

Welders and bench fitters

Metal-processing managers

Assembly-line workers

Mechanics

Mechanical engineering designers and heads of technical service departments

Electronical engineers

Fitters and electronic product controllers

Electrical engineers

Electrotechnical designers and managers

Electrical engineers

Printing industry production workers

Skilled printing workers

Mechanical operators

Process operators

Process technicians.

Material scientists

Textile workers

Cobblers and tailors

Loaders and unloaders

Drivers

Ship's officers and conductors

Pilots, ship captains and transport directors

Stewards

Nursing aids and student nurses

Nurses and medical assistants

Therapists and nurses

Physicians

Pharmacy assistants medical laboratory staff Medical analysts

Pharmacists

Department heads in care institutions

Office assistants, packers and door-to-door salesmen

Auxiliary administrative assistants

Managers

Economists

Production planners

Organisational consultants

Organisational experts

Receptionists and administrative employees

Accountants and secretaries

Assistant accountants

Accountants

\begin{tabular}{|c|c|c|c|c|c|}
\hline $\begin{array}{l}\text { medium } \\
\text { low } \\
\text { high } \\
\text { high }\end{array}$ & $\begin{array}{l}\text { medium } \\
\text { low } \\
\text { high } \\
\text { high }\end{array}$ & $\begin{array}{l}\text { medium } \\
\text { low } \\
\text { high } \\
\text { high }\end{array}$ & $\begin{array}{l}\text { medium } \\
\text { low } \\
\text { medium } \\
\text { medium }\end{array}$ & $\begin{array}{l}\text { high } \\
\text { high } \\
\text { low } \\
\text { low }\end{array}$ & $\begin{array}{l}\text { medium } \\
\text { high } \\
\text { low } \\
\text { low }\end{array}$ \\
\hline $\begin{array}{l}\text { high } \\
\text { high } \\
\text { high } \\
\text { medium } \\
\text { high } \\
\text { high }\end{array}$ & $\begin{array}{l}\text { medium } \\
\text { high } \\
\text { high } \\
\text { high } \\
\text { high } \\
\text { high }\end{array}$ & $\begin{array}{l}\text { medium } \\
\text { high } \\
\text { high } \\
\text { medium } \\
\text { high } \\
\text { high }\end{array}$ & $\begin{array}{l}\text { medium } \\
\text { high } \\
\text { high } \\
\text { medium } \\
\text { high } \\
\text { high }\end{array}$ & $\begin{array}{l}\text { high } \\
\text { low } \\
\text { low } \\
\text { low } \\
\text { low } \\
\text { medium }\end{array}$ & $\begin{array}{l}\text { medium } \\
\text { low } \\
\text { low } \\
\text { medium } \\
\text { low } \\
\text { low }\end{array}$ \\
\hline $\begin{array}{l}\text { high } \\
\text { medium } \\
\text { high } \\
\text { high } \\
\text { medium } \\
\text { low } \\
\text { high } \\
\text { high } \\
\text { high } \\
\text { high } \\
\text { high } \\
\text { medium } \\
\text { high } \\
\text { high } \\
\text { high } \\
\text { medium } \\
\text { high } \\
\text { high } \\
\text { high } \\
\text { medium } \\
\text { medium } \\
\text { low } \\
\text { medium } \\
\text { medium } \\
\text { medium } \\
\text { low } \\
\text { low }\end{array}$ & $\begin{array}{l}\text { high } \\
\text { high } \\
\text { high } \\
\text { high } \\
\text { high } \\
\text { medium } \\
\text { high } \\
\text { high } \\
\text { high } \\
\text { high } \\
\text { medium } \\
\text { medium } \\
\text { high } \\
\text { high } \\
\text { high } \\
\text { high } \\
\text { high } \\
\text { medium } \\
\text { medium } \\
\text { low } \\
\text { medium } \\
\text { medium } \\
\text { medium } \\
\text { high } \\
\text { high } \\
\text { medium } \\
\text { low }\end{array}$ & $\begin{array}{l}\text { medium } \\
\text { medium } \\
\text { high } \\
\text { high } \\
\text { medium } \\
\text { low } \\
\text { medium } \\
\text { high } \\
\text { high } \\
\text { high } \\
\text { medium } \\
\text { medium } \\
\text { high } \\
\text { medium } \\
\text { high } \\
\text { high } \\
\text { medium } \\
\text { medium } \\
\text { high } \\
\text { high } \\
\text { high } \\
\text { high } \\
\text { medium } \\
\text { medium } \\
\text { medium } \\
\text { low } \\
\text { medium }\end{array}$ & $\begin{array}{l}\text { medium } \\
\text { high } \\
\text { high } \\
\text { high } \\
\text { low } \\
\text { low } \\
\text { high } \\
\text { high } \\
\text { high } \\
\text { high } \\
\text { medium } \\
\text { medium } \\
\text { medium } \\
\text { medium } \\
\text { high } \\
\text { high } \\
\text { high } \\
\text { high } \\
\text { high } \\
\text { high } \\
\text { high } \\
\text { high } \\
\text { medium } \\
\text { high } \\
\text { high } \\
\text { medium } \\
\text { medium }\end{array}$ & $\begin{array}{l}\text { high } \\
\text { medium } \\
\text { low } \\
\text { medium } \\
\text { medium } \\
\text { medium } \\
\text { medium } \\
\text { medium } \\
\text { low } \\
\text { medium } \\
\text { medium } \\
\text { high } \\
\text { low } \\
\text { high } \\
\text { low } \\
\text { medium } \\
\text { medium } \\
\text { high } \\
\text { high } \\
\text { medium } \\
\text { medium } \\
\text { medium } \\
\text { high } \\
\text { low } \\
\text { medium } \\
\text { high } \\
\text { medium }\end{array}$ & $\begin{array}{l}\text { high } \\
\text { medium } \\
\text { low } \\
\text { low } \\
\text { high } \\
\text { high } \\
\text { medium } \\
\text { low } \\
\text { low } \\
\text { medium } \\
\text { medium } \\
\text { high } \\
\text { low } \\
\text { low } \\
\text { low } \\
\text { low } \\
\text { medium } \\
\text { medium } \\
\text { low } \\
\text { low } \\
\text { medium } \\
\text { low } \\
\text { medium } \\
\text { medium } \\
\text { high } \\
\text { medium } \\
\text { medium }\end{array}$ \\
\hline $\begin{array}{l}\text { high } \\
\text { high } \\
\text { medium } \\
\text { low } \\
\text { medium } \\
\text { medium } \\
\text { low } \\
\text { low } \\
\text { low } \\
\text { low } \\
\text { low }\end{array}$ & $\begin{array}{l}\text { medium } \\
\text { medium } \\
\text { medium } \\
\text { low } \\
\text { medium } \\
\text { medium } \\
\text { low } \\
\text { medium } \\
\text { low } \\
\text { low } \\
\text { low }\end{array}$ & $\begin{array}{l}\text { high } \\
\text { medium } \\
\text { medium } \\
\text { low } \\
\text { medium } \\
\text { low } \\
\text { low } \\
\text { medium } \\
\text { low } \\
\text { low } \\
\text { low }\end{array}$ & $\begin{array}{l}\text { high } \\
\text { low } \\
\text { medium } \\
\text { low } \\
\text { high } \\
\text { medium } \\
\text { low } \\
\text { medium } \\
\text { low } \\
\text { low } \\
\text { low }\end{array}$ & $\begin{array}{l}\text { low } \\
\text { low } \\
\text { high } \\
\text { high } \\
\text { high } \\
\text { high } \\
\text { high } \\
\text { low } \\
\text { medium } \\
\text { high } \\
\text { high }\end{array}$ & $\begin{array}{l}\text { low } \\
\text { medium } \\
\text { high } \\
\text { high } \\
\text { high } \\
\text { high } \\
\text { high } \\
\text { high } \\
\text { high } \\
\text { high } \\
\text { high }\end{array}$ \\
\hline
\end{tabular}


Insurance brokers

Purchasing clerks

medium low

low low

medium high

Table A2 (continued)

Occupational job strain level, by job strain indicator, 1996

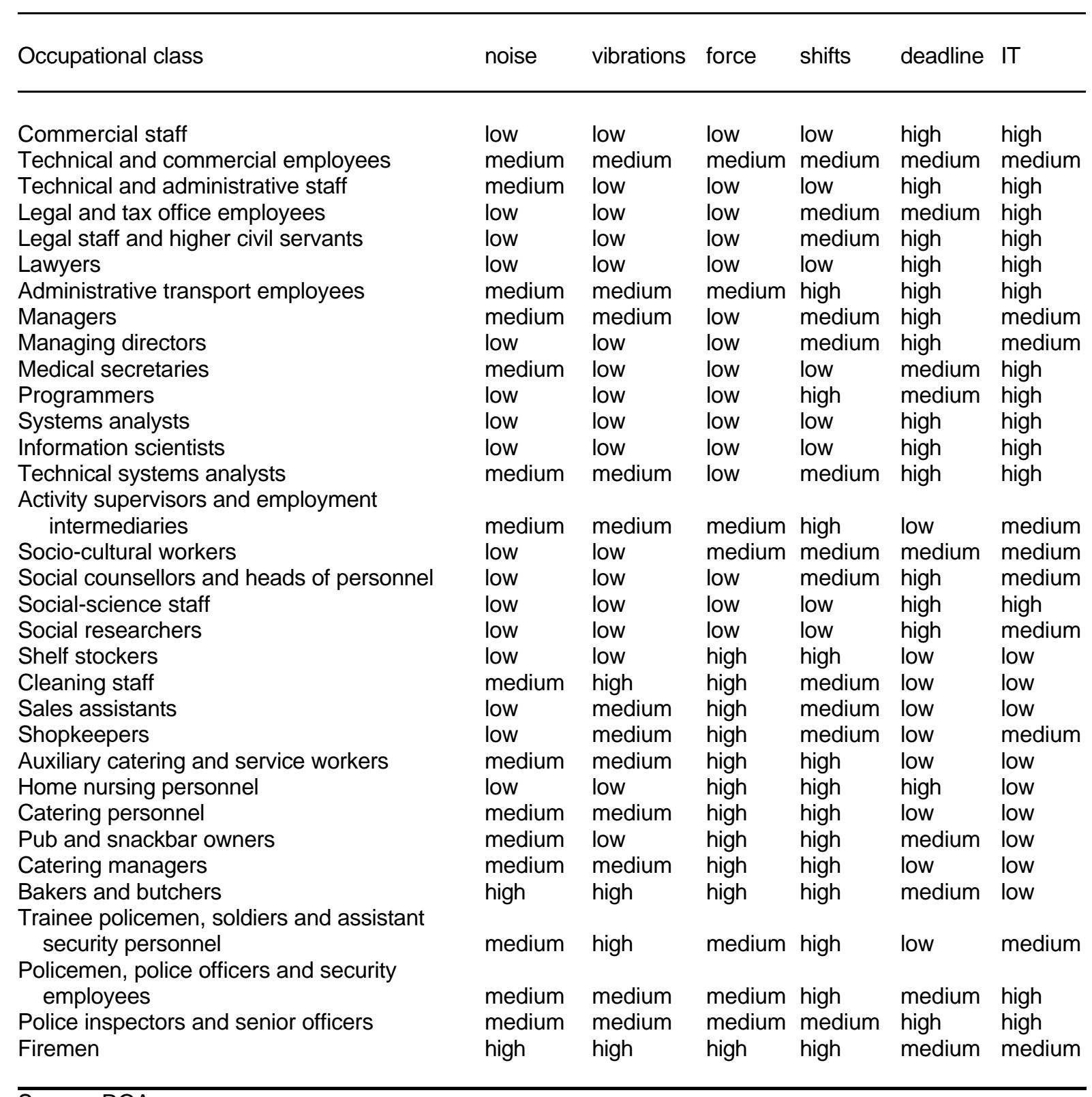

Source: ROA 